\title{
NAJWYŻSZY URZĄD KONTROLI REPUBLIKI CZESKIEJ
}

\begin{abstract}
Streszczenie. W artykule ukazana jest geneza, ewolucja, obecna pozycja ustrojowa oraz zakres podmiotowy i przedmiotowy Najwyższego Urzędu Kontroli Republiki Czeskiej. Jego początki sięgają czasów powstania Czechosłowacji po I wojnie światowej. W późniejszych latach był on zastępowany przez ministerstwo kontroli. Lakoniczność obowiązującej konstytucyjnej regulacji tego organu nie pozwala na precyzyjne określenie jego pozycji ustrojowej i chociaż nie można uznać go za czwarty segment władzy, niewątpliwie jest ona specyficzna. Wątpliwości budzi również zakres przedmiotowy i podmiotowy sprawowanej przez niego kontroli.
\end{abstract}

Słowa kluczowe: funkcja kontrolna państwa, kontrola państwowa, Najwyższy Urząd Kontroli, Republika Czeska.

Pojawienie się skarbu państwa uczyniło koniecznym powstanie instytucji zajmującej się badaniem gospodarowania środkami publicznymi. Doprowadziło to do stworzenia wyspecjalizowanej grupy organów kontroli państwowej, których zadaniem jest nie tylko analiza z różnych punktów widzenia dochodów i wydatków państwa (budżetu), ale również dążenie do poprawienia działalności całej administracji państwowej. Organy takie, pod różną nazwą, funkcjonują na całym świecie, mając przy tym różny podmiotowy i przedmiotowy zakres kontroli. Ponieważ najczęściej budżet przyjmowany jest przez parlament w formie ustawy, zaś za jego wykonanie odpowiada władza wykonawcza, w doktrynie prawa konstytucyjnego zrodziło to pytanie zarówno o usytuowanie organów kontroli w systemie organów państwa $z$ uwagi na przyjmowaną powszechnie zasadę trójpodziału władzy, jak i o funkcje współczesnego państwa. Dlatego pojawiła się teza o wydzieleniu odrębnej funkcji kontrolnej państwa, jak i istnieniu, obok władzy ustawodawczej, władzy wykonawczej i władzy sądowniczej, czwartej władzy - władzy kontrolnej (kontrolującej) (Sylwestrzak 2006, 19). I chociaż w literaturze przedmiotu nie jest ona jednak powszechnie akceptowana, stawiane pytanie i wywołany problem są przedmiotem dyskusji przedstawicieli doktryny prawa konstytucyjnego wielu państw.

Ćwierćwiecze uchwalenia Konstytucji Republiki Czeskiej, oraz funkcjonowania Republiki Czeskiej jako samodzielnego państwa na arenie międzynarodowej,

${ }^{*}$ Uniwersytet Łódzki, Wydział Prawa i Administracji, Katedra Prawa Konstytucyjnego, kskotnicki@wpia.uni.lodz.pl. 
jest okazją, aby zwrócić uwagę nie tylko na takie jego organy jak parlament składający się z Izby Poselskiej i Senatu, dualistyczną władzę wykonawczą tworzoną przez prezydenta i rząd, czy sądownictwo, ze szczególnym podkreśleniem znaczenia Sądu Konstytucyjnego, ale i na inne, wśród których jest Najwyższy Urząd Kontroli. Organowi temu w polskiej literaturze z zakresu prawa konstytucyjnego nie poświęcono, jak dotąd, więcej uwagi, trudno również mówić o tym, aby wiele prac na jego temat można było odnaleźć w piśmiennictwie czeskim ${ }^{1}$, jest też wiele prac, w których omówienie tego organu jest pomijane (Pavlíček a kol. 1998). Opracowanie ma celu przybliżenie polskiemu czytelnikowi tego urzędu.

W czeskiej doktrynie prawa konstytucyjnego początków kontroli państwowej na ziemiach czeskich zgodnie upatruje się w utworzonej w Austrii w 1761 roku Dworskiej Izbie Obrachunkowej². W 1866 roku została zastąpiona przez Najwyższą Izbę Obrachunkową. Organ ten był podporządkowany bezpośrednio panującemu, niezależny od innych ministerstw i z nimi równorzędny, a jego głównym zadaniem była analiza wykonania i wyników gospodarowania finansami (Pavlíček a kol. 2015, 1022).

W rodzącej się po I wojnie światowej Czechosłowacji jej tymczasowa konstytucja z 13 listopada 1918 roku ograniczyła się tylko do uregulowania stosunków między Zgromadzeniem Narodowym, prezydentem i rządem i niczego nie stanowiła o organach kontroli państwowej. O znaczeniu, jakie przywiązywano do kontroli państwowe, świadczy jednak to, że już 20 marca 1919 roku została uchwalona ustawa o ustanowieniu i kompetencjach Najwyższego Obrachunkowego Urzędu Kontroli (dalej NOUK), która w przepisach końcowych w § 14 uchyliła podstawę prawną funkcjonowania austriackiej Najwyższej Izby Obrachunkowej. Ustawa określiła, iż NOUK utworzony jest w celu nadzorowania gospodarki państwowej, majątku państwa i długu państwowego Republiki Czeskiej (§ 1 zdanie pierwsze). Jednocześnie przesądziła, że jest on odrębny i równoważny ministerstwom, jednak od nich niezależny ( 1 zdanie drugie). Na czele NOUK stał przewodniczący powoływany (mianowany) przez Prezydenta na wniosek rządu (§ 2 zdanie drugie). Przewodniczący ponosił odpowiedzialność za działalność NOUK przed Zgromadzeniem Narodowym (parlamentem). Kontrola sprawowana przez NOUK obejmowała wszystkie urzędy administracji i przede wszystkim odnosiła się do wykonania przez nie budżetu państwa. Do niego należało też coroczne sporządzenie państwowego budżetu końcowego i przedstawianie go

${ }^{1} \mathrm{~W}$ piśmiennictwie tym przede wszystkim wskazać należy, napisany bezpośrednio po uchwaleniu Konstytucji Republiki Czeskiej z 1992 r., artykuł V. Mikulego, Nejvyšší kontrolní úř́ad po novu (1993) oraz liczne komentarze do Konstytucji oraz podręczniki prawa konstytucyjnego. Najczęściej są to odwołania do licznych komentarzy do Konstytucji Republiki Czeskiej z 1992 r.

${ }^{2}$ W Polsce odwołujemy się w tym przypadku do Trybunału Skarbowego powołanego w 1591 r., który w XVIII w. został zastąpiony przez dwie komisje skarbowe - Koronną i Wielkiego Księstwa Litewskiego.

${ }^{3}$ Ustawa nr 175/1919 Sb. 
Zgromadzeniu Narodowemu. Przewodniczący NOUK miał obowiązek uczestniczenia w pracach Zgromadzenia Narodowego, podczas którego musiał mieć możliwość zabrania głosu, jeżeli o to poprosił, z głosem doradczym uczestniczył też w posiedzeniach rządu.

Naczelny Obrachunkowy Urząd Kontroli funkcjonował w Czechosłowacji aż do 1951 roku, kiedy to w czasach stalinowskich, podobnie jak i w innych państwach bloku socjalistycznego, został zastąpiony przez ministerstwo kontroli państwowej. Zostało to uczynione na podstawie wydanego, za zgodą prezydenta, rozporządzenia rządu z 7 września 1951 roku o utworzeniu ministerstwa kontroli państwowej ${ }^{4}$. Tym samym najwyższy organ kontroli państwowej przestał był organem niezależnym, lecz stał się częścią władzy wykonawczej.

Ministerstwo kontroli działało tylko przez 10 lat i zostało zlikwidowane w związku z uchwaleniem ustawy z 19 września 1961 roku o kontroli państwowej, statystyce i innych działach ewidencji gospodarki narodowej ${ }^{5}$. Nie oznaczało to jednak zmiany w usytuowaniu kontroli państwowej, na mocy $\S 5$ ust. 1 tej ustawy został bowiem utworzony Centralny Urząd Kontroli Państwowej i Statystyki, na czele z przewodniczącym, będącym ministrem. Nadal nie był to zatem organ niezależny. Jak podkreśla przy tym M. Tomoszek, działalność tego organu z uwagi na ówczesną sytuację polityczną skupiona była głównie na wypełnianiu planu przez podmioty zajmujące się produkcją (Jirásek a kol. 2013, 313).

Przywrócenie niezależności organów kontroli nastąpiło (na krótko) w czasie wydarzeń z lat 1968-1969. Stało się to na podstawie ustawy Czeskiej Rady Narodowej z 24 stycznia 1969 roku o Najwyższym Urzędzie Kontroli Czeskiej Republiki Socjalistycznej ${ }^{6}$. W § 1 ust. 1 ustanowiono, że jest to organ Czeskiej Rady Narodowej, przed którą ponosi odpowiedzialność. Na jego czele stał Kontroler Generalny powoływany przez Czeską Radę Narodową na okres swojej kadencji, który przed nią odpowiadał i przez którą mógł być odwołany ( 6 ust. 1). Generalny Kontroler miał swojego zastępcę powoływanego i odwoływanego na jego wniosek przez Czeską Radę Narodową oraz swój organ doradczy w postaci Rady. Jego zadaniem była pomoc dla organu ustawodawczego w sprawowaniu kontroli politycznej. Należy podkreślić, że był to organ utworzony wyłącznie w Czechach, natomiast $w$ powstałej federacji czechosłowackiej idea niezależnego organu kontroli państwowej znalazła wyraz jedynie w projektach ustaw? ${ }^{7}$.

${ }^{4}$ Rozporządzenie $\mathrm{nr} 73 / 1951 \mathrm{Sb}$. zostało wydane na podstawie $\S 1$ ustawy konstytucyjnej nr 47/1950 Sb. o korektach w organizacji administracji publicznej, które przyznało rządowi m.in. prawo tworzenia ministerstw.

${ }^{5}$ Ustawa nr 99/1961 Sb.

${ }^{6}$ Ustawa nr 7/69 Sb.

${ }^{7}$ W Zgromadzeniu Narodowym Czechosłowackiej Republiki Socjalistycznej IV kadencji był to druk nr 230, natomiast w Zgromadzeniu Federalnym Czechosłowackiej Republiki Socjalistycznej I kadencji był to druk nr 7 (o Izbie Kontrolnej CSRS). Zob. Filip (2010). 
Funkcjonowanie Najwyższego Urzędu Kontroli było niesłychanie krótkie, gdyż już 22 grudnia 1970 roku Czeska Rada Narodowa uchwaliła ustawę o zmianach $\mathrm{w}$ systemie ministerstw i innych centralnych organach administracji państwowej Czeskiej Republiki Socjalistycznej ${ }^{8}$. Na jej podstawie utworzono Komitet Kontroli Ludowej, który był centralnym organem administracji państwowej. Tym samym ponownie wprowadzono dyrektywny sposób zarządzania.

Zmiany i powrót zarówno do niezależnego organu kontroli, jak i parlamentarnej formy rządów, stał się możliwy dopiero po roku 1989. W dużej mierze nastąpiło to pod wpływem dokumentów przyjętych przez Międzynarodową Organizację Najwyższych Organów Kontroli (International Organization of Supreme Audit Institutions - INTOSAI) i przede wszystkim jej tzw. deklaracji z Limy, która przez Zgromadzenie Ogólne ONZ została uznana za kluczową w określeniu niezależności organów kontroli na świecie. Nie bez znaczenia było również dążenie najpierw Czechosłowacji, a później Republiki Czeskiej, do przystąpienia do Unii Europejskiej oraz ich współpraca z Europejskim Trybunałem Obrachunkowym.

Jeszcze przed rozpadem federacji Czeska Rada Narodowa uchwaliła 7 listopada 1991 roku ustawę konstytucyjną o ustanowieniu Najwyższego Urzędu Kontroli Republiki Czeskiej ${ }^{9}$ (dalej: NUK), w której wyraźnie określono, że jest on niezawisły i niezależny od rządu, jego organów i innych centralnych organów administracji państwowej (§ 1). Wskazany akt prawny nie regulował jednak jakichkolwiek szczegółów odnośnie do NUK, lecz odsyłał do ustawy. Jej uchwalenie napotkało jednak na duże problemy (Mikule 1993) i do jej przyjęcia doszło dopiero po uchwaleniu Konstytucji Republiki Czeskiej w dniu 16 grudnia 1992 roku $^{10}$. Co ciekawe, analogicznego organu kontroli nie powołano w federacji, jak i w Słowacji (Gerloch, Hřebejk, Zoubek 1999, 244).

Regulacja konstytucyjna odnośnie do Najwyższego Urzędu Kontroli Republiki Czeskiej jest bardzo lakoniczna; poświęcony jest mu wprawdzie osobny rozdział $\mathrm{V}$, zawiera on jednak tylko jedynie niezbyt rozbudowany artykuł (art. 97), który przesądza ogólnie o usytuowaniu NKU w systemie organów państwa i przedmiocie sprawowanej przez niego kontroli (ust. 1), prezydencie i wiceprezydencie oraz sposobie ich powołania (ust. 2) oraz odsyła do ustawy, która ma szczegółowo uregulować jego pozycję, kompetencje, strukturę organizacyjną i inne szczegóły (ust. 3) ${ }^{11}$. Regulacją tą jest ustawa z 20 maja 1993 roku o Najwyższym Urzędzie Kontroli ${ }^{12}$; do czasu wejścia jej w życie obowiązywały przepisy ustaw z 1991 roku i 1992 roku. Do działalności NKU odnoszą się również postanowienia innych ustaw: z 27 czerwca 2000 roku o zasadach budżetowych

\footnotetext{
${ }^{8}$ Ustawa nr 147/1970 Sb.

${ }^{9}$ Ustawa konstytucyjna $\mathrm{nr}$ 481/1991 Sb.

${ }^{10}$ Ustawa konstytucyjna $\mathrm{nr} 1 / 1993 \mathrm{Sb}$.

11 Jest to bardzo wyraźnie widoczne przy porównaniu np. z polską regulacją, w której Najwyższa Izba Kontroli uregulowana jest stosunkowo szczegółowo w art. 202-207.

${ }^{12}$ Ustawa nr 166/1993 Sb. ze zm.
} 
i zmianie niektórych powiązanych aktów prawnych (zasady budżetowe) ${ }^{13}$, z 27 czerwca 2000 roku o majątku Republiki Czeskiej i jej reprezentacji w stosunkach prawnych ${ }^{14}, \mathrm{z} 9$ sierpnia 2001 roku o kontroli finansowej w administracji publicznej i zmianie niektórych aktów prawnych (ustawa o kontroli finansowej) $)^{15}$ oraz z 14 marca 2006 roku o zamówieniach publicznych ${ }^{16}$.

Umiejscowienie NKU w oddzielnym rozdziale Konstytucji skłania nielicznych czeskich autorów do przychylenia się w sporze doktryny prawa konstytucyjnego o liczbę władz do tezy, że można mówić, iż jest to czwarta władza kontrolna $^{17}$, albo czwarty filar demokracji (Gerloch, Hřebejk, Zoubek 1999, 136). V. Pavlíček i J. Hřebejk piszą, że jest to odejście od koncepcji trójpodziału władzy na rzecz zasady różnych organów w mechanizmie państwa (Pavlíček, Hřebejk 1998, 327). Z materialnego punktu widzenia sprawowana przez NKU kontrola jest działalnością administracyjną, z formalnego punktu widzenia nie jest to jednak działalność urzędu administracyjnego w rozumieniu art. 79 Konstytucji. Będąc dlatego urzędem (organem) państwowym nie jest, co słusznie podkreśla V. Mikule, i nie może być traktowany jako centralny urząd administracji państwowej (Pavlíček a kol. 2015, 1025). O. Pouperová $(2008,142)$ zasadnie podnosi jednak, że jest to organ władzy publicznej. K. Klíma akcentuje z kolei, że organ ten oprócz uprawnień kontrolnych nie dysponuje żadną władzą w stosunku do innych organów państwa, w związku z czym konstatuje, że NKU nie można uznać za kolejny typ władzy państwowej, lecz należy w jego przypadku mówić tylko o szczególnym organie konstytucyjnym (Klíma 2002, 390). Jan Filip podnosi natomiast, że z materialnego punktu widzenia nie jest to organ władzy ustawodawczej bądź sądowniczej, blisko mu jednak do różnych organów kontroli państwowej w ramach wykonywania funkcji kontrolnej, jak chociażby wszelkiego rodzaju inspekcji (handlowej, szkolnej, energetycznej) bądź organów kontroli finansowej (ministerstwo finansów) (Filip 2010, Uwagi 5 i 6...). W polskiej literaturze przedmiotu do poglądu o umiejscowieniu NKU poza trójpodziałem władzy na ustawodawczą, wykonawczą i sądowniczą zasadnie, moim zdaniem, przychyla się M. Bankowicz $(1998,185)$.

Konstytucja w art. 97 ust. 1 stanowi przede wszystkim o tym, że NKU to niezawisły organ Republiki Czeskiej. Z regulacji tej wynika, że jest to samodzielny, niezależny organ konstytucyjny, a tym samym nie jest to organ pomocniczy czy doradczy jakiegokolwiek innego organu. Jego niezawisłość oznacza, że w działalności jest on związany wyłącznie ustawą, sam organizuje swoją aktywność i nie przyjmuje, a w szczególności nie jest związany instrukcjami żadnego innego

${ }^{13}$ Ustawa nr 218/2000 Sb. ze zm.

${ }^{14}$ Ustawa nr 219/2000 Sb. ze zm.

${ }^{15}$ Ustawa nr 320/2001 Sb. ze zm.

${ }^{16}$ Ustawa nr 137/2006 Sb. ze zm.

${ }^{17} \mathrm{O}$ poglądach takich pisze Filip (2001, 200 i n.) Pytanie to stawia również Klíma; zob. Klíma a kol. $(2005,500)$. 
organu (Klíma a kol. 2002, 500). W literaturze przedmiotu zarazem podkreśla się, że niezawisłość ta jest jednak węższa niż ma to miejsce w przypadku sądów (art. 81 Konstytucji) (Pavlíček a kol. 2015, 1025). W czeskiej doktrynie akcentuje się jego niezawisłość personalną i instytucjonalną. W pierwszym przypadku niezawisłość gwarantuje sposób powoływania i odwoływania prezydenta i wiceprezydenta NKU, ustawowe określenie wysokości ich płacy oraz wyłączna odpowiedzialność karna prezydenta, wiceprezydenta i członków NKU przed Izbą Karną NKU. W drugim przypadku jest to: wyłączenie z systemu trójpodziału władzy, przyjęcie szerokiej zasady niepołączalności funkcji prezydenta, wiceprezydenta i członków NKU z innymi funkcjami, sposób jego finansowania poprzez posiadanie własnego rozdziału w budżecie państwa, powierzenie kontroli nad gospodarowaniem przez NKU jego majątkiem wyłącznie Izbie Poselskiej lub utworzonemu przez nią organowi, wreszcie wykluczenie możliwości innych organów konstytucyjnych zlecenia do wykonania zadań czy wskazówek, lecz jedynie stawianie niewiążących wniosków (Jirásek a kol. 2013, 314-315). J. Filipa prowadzi to do wniosku, że niezawisłość instytucjonalnie chroni NKU nie tylko przed egzekutywą, ale i przez działalnością ustawodawcy, który może wprawdzie na podstawie art. 79 ust. 1 Konstytucji odnosić się do niego jako do urzędu administracyjnego, nie ma jednak możliwości wkraczania w jego istotę jako niezawisłego organu kontroli gospodarowania majątkiem państwowym oraz wykonania budżetu państwa; uważa dlatego, że art. 97 ust. 1 należy traktować jako przepis lex specialis (Filip 2010, Uwaga 21...).

Jak już wskazywałem, Konstytucja nader ogólnie odnosi się do organizacji Najwyższego Urzędu Kontroli, przesądzając jedynie, że ma być w nim prezydent i wiceprezydent mianowani przez Prezydenta $\mathrm{RCz}$ na wniosek Izby Poselskiej (art. 97 ust. 2). Ustawa o NKU stanowi natomiast, że organami NKU są prezydent NKU, wiceprezydent NKU, Kolegium NKU, senaty NKU i Izba Karna NKU.

W przypadku prezydenta i wiceprezydenta ustawa stanowi, że mogą nimi zostać jedynie pełnoprawni obywatele Republiki Czeskiej, którzy ukończyli 35 lat, spełniają warunki określone w tzw. ustawie lustracyjnej, mają ukończone wyższe studia magisterskiej, są nieskazitelni oraz mają doświadczenie i cechy moralne gwarantujące, że będą należycie wykonywać swoje obowiązki. Kandydaci mogą być zgłaszani wyłącznie przez kluby poselskie ${ }^{18}$. Zgodnie z ogólnymi zasadami wybór dokonywany jest większością głosów w obecności co najmniej jednej trzeciej ogólnej liczby posłów. Przepisy dopuszczają wprawdzie możliwość przeprowadzania w takim przypadku głosowania jawnego, jak podaje jednak J. Filip, w praktyce Izba podejmuje zawsze decyzję, że głosować będzie w takiej sprawie tajnie (Filip 2010, Uwaga 46...). W literaturze przedmiotu toczy się natomiast

${ }^{18}$ Wynika to z art. 6 ust. 1 Regulaminu wyborów dokonywanych przez Izbę Poselską i nominacji wymagających zgody Izby Poselskiej, który stanowi Załącznik nr 2 do ustawy z dnia 19 kwietnia 1995 r. Regulamin obrad Izby Poselskiej Parlamentu Republiki Czeskiej (ustawa nr 90/1995 Sb. ze zm.). 
spór, czy Prezydent $\mathrm{RCz}$ przedstawionego mu kandydata na prezydenta NKU bądź wiceprezydenta NKU musi mianować; za takim obowiązkiem głowy państwa opowiada się K. Klíma (Klíma a kol. 2002, 501), odmiennego zdania jest natomiast J. Filip, taka sytuacja miała też miejsce już w praktyce (Filip, Uwaga 47... 2010). Objęcie funkcji następuje $\mathrm{z}$ chwilą złożenia ślubowania na ręce Prezydenta $\mathrm{RCz}^{19}$.

Konstytucja nie stanowi niczego na temat kadencji prezydenta NKU i wiceprezydenta NKU. Pozostawienie uregulowania tej kwestii ustawie może zastanawiać i niewątpliwie nie wzmacnia niezawisłości całego urzędu. Zgodnie z $§ 10$ ust. 2 ustawy o NKU kadencja ta wynosi 9 lat. Ustawa w $\S 10$ ust. 8 przewiduje też sytuacje, w których funkcje te dobiegają końca. Są nimi: upływ kadencji, złożenie rezygnacji, prawomocne ograniczenie wyrokiem sądu pełni praw bądź prawomocny wyrok skazujący za czyn karny, a także odwołanie na wniosek Izby Deputowanych przez Prezydenta RCz; odwołanie, zgodnie z $§ 10$ ust. 9, może przy tym nastąpić wyłącznie w przypadku niewykonywania funkcji przez dłużej niż sześć miesięcy lub na podstawie prawomocnego wyroku Izby Karnej NKU, w którym uznano, że dopuścił się on takiego przewinienia karnego, za które nałożona jest sankcja w postaci wniosku o odwołanie. W czeskiej literaturze przedmiotu podnoszone jest, że Konstytucja nie przyznaje Prezydentowi prawa do odwołania prezydenta NKU i wiceprezydenta NKU, co musi rodzić pytanie o możliwość jego ustanowienia w ustawie; zarazem przypomina się jednak, że czeski Sąd Konstytucyjny wskazał, iż NKU (w przeciwieństwie do rządu) nie ponosi przed parlamentem odpowiedzialności politycznej, co pozwala na określenie przesłanek umożliwiających takie odwołanie (Pavlíček a kol. 2015, 1026 i 1027).

Prezydent NKU przede wszystkim kieruje NKU, reprezentuje go na zewnątrz, przewodniczy Kolegium Urzędu i Izbie Karnej Urzędu, a po rozpatrzeniu przez Kolegium NKU nadaje Regulamin organizacyjny i pracy NKU ( $\$ 8$ ustawy). Ma też prawo uczestniczenia w posiedzeniach Izby Poselskiej i Senatu oraz ich organów, jeżeli są rozpatrywane sprawy wniesione przez NKU, jak i musi mu być wówczas udzielony głos, jeżeli o to poprosi. Wiceprezydent NKU zastępuje prezydenta NKU w okresie jego nieobecności i w innych sprawach powierzonych mu przez prezydenta NKU, może mu być również powierzone wykonywanie niektórych zadań przewodniczącego NKU na podstawie regulaminu organizacyjnego i pracy NKU (§ 9 ustawy $)^{20}$.

${ }^{19}$ Rota ślubowania jest następująca: „Ślubuję wierność Republice Czeskiej. Ślubuje przestrzegać Konstytucję i ustawy. Ślubuję na swoją cześć, że będę swoją funkcję wykonywać niezależnie i bezstronnie, i że nie nadużyję swojego stanowiska".

${ }^{20}$ Ponieważ wiceprezydent NKU nie posiada własnych kompetencji, w świetle poglądów polskiej doktryny można zastanawiać się, czy zasadnie ustawa o Najwyższym Urzędzie Kontroli zalicza go do organów Urzędu. Przykładowo, wicemarszałkowie Sejmu nie są organami Sejmu i to pomimo wymienienia ich w konstytucji. 
Ustawa przewiduje również, że prezydent, wiceprezydent i członkowie NKU nie mogą być posłami, senatorami, sędziami, przedstawicielami państwa, nie mogą także pełnić jakichkolwiek funkcji w administracji publicznej, być członkami organów samorządu terytorialnego, ani pełnić funkcji w partiach politycznych i ruchach politycznych ( $\$ 10$ ust. 7 i $\S 12$ ust. 7 ustawy).

W skład NKU wchodzi następnie 15 członków, którzy są powoływani przez Izbę Poselską na wniosek prezydenta NKU (§ 12 ust. 1 ustawy). Kandydaci muszą spełniać te same warunki, co kandydaci na funkcję prezydenta lub wiceprezydenta NKU, wystarczy jednak, że mają ukończone tylko 30 lat (\$12 ust. 3 ustawy). Przepisy nie ustanawiają kadencyjności członkostwa w NKU, co oznacza, iż mogą oni pełnić tę funkcję do ukończenia 65 lat. Podobnie jak prezydent i wiceprezydent mogą być jednak z tych samych przyczyn odwołani przez Izbę Poselską na wniosek prezydenta NKU.

Prezydent, wiceprezydent i członkowie NKU tworzą wspólnie Kolegium NKU. W czeskiej literaturze przedmiotu zgodnie podkreśla się, że organ ten jest przeciwwagą dla monokratycznych organów NKU; przesądzają o tym jego kompetencje, wśród których najważniejszymi są uchwalanie: planów kontroli, projektu budżetu NKU przedkładanego Izbie Poselskiej, wniosków końcowych stanowiących podstawę stanowiska odnośnie do projektu budżetu państwa, rocznego sprawozdania, regulaminów pracy Kolegium, organizacyjnego i karnego.

Kolegium tworzy ze swojego składu senaty (§14 ustawy). Czynione jest to przy uchwalaniu planu kontroli, z jednoczesnym wyznaczaniem im zadań. Senaty muszą liczyć co najmniej trzech członków. Oprócz uprawnień kontrolnych, w niektórych przypadkach pełnią one również rolę organów odwoławczych (§ 27 ust. 3 lit. b ustawy). Ich decyzje są ostateczne i nie mogą być zmienione przez prezydenta NKU ani Kolegium NKU.

Bardzo istotna rola w ustawie o Najwyższym Urzędzie Kontroli przypisana jest Izbie Karnej NKU (§ 38). Składa się ona z trzech członków. Z urzędu przewodniczy jej prezydent NKU, z wyjątkiem sytuacji, gdy sprawa go dotyczy (wówczas jest zastępowany przez wiceprezydenta). Pozostałych dwóch członków mianuje przewodniczący Sądu Najwyższego spośród sędziów tego sądu. Rozpoznając sprawy prezydenta, wiceprezydenta czy członków NKU Izba może orzec następujące środki karne: upomnienie, obniżenie wynagrodzenia o $15 \%$ na okres do sześciu miesięcy lub wniosek o odwołanie z funkcji.

Jak już podkreślałem, Konstytucja w art. 97 ust. 1 określiła kompetencje Najwyższego Urzędu Kontroli na sprawowanie kontroli gospodarowania majątkiem państwowym oraz wykonania budżetu państwa. Jak podkreślił Sąd Konstytucyjny, oznacza to, że nie może on wykonywać nic mniej, ani nic więcejej ${ }^{21}$ Skonkretyzowanie odnośnie do zakresu przedmiotowego i podmiotowego tej kontroli reguluje w $\S 3$ ustawa o NKU. Zgodnie z nim jest to kontrola: a) gospodarowania

${ }^{21}$ Zob. wyrok nr 296/1995. 
majątkiem państwowym i zasobami finansowymi uzyskanymi na mocy ustawy przez osoby prawne, z wyjątkiem środków uzyskanych przez gminy lub kraje w związku z ich kompetencjami, b) państwowego rachunku końcowego, c) wykonania budżetu państwa, d) gospodarowania funduszami przekazanymi Republice Czeskiej z zagranicy oraz środkami, na które państwo udzieliło gwarancji, e) emisji i amortyzacji rządowych papierów wartościowych, f) zamówień publicznych.

W czeskiej literaturze przedmiotu J. Filip podnosi, że pojęcia ,gospodarowanie majątkiem państwowym” i ,wykonanie budżetu państwa” nie są precyzyjne, ponieważ są jednak konstytucyjne, muszą być wykładane autonomicznie, a próba ich ustawowego doprecyzowania, czy zmiany, nie powiodła się. Stąd dla ich rozumienia znaczenie ma przede wszystkim praktyka, jako że orzecznictwo jest skromne (Filip 2010, Uwaga 33...). V. Mikule wskazuje z kolei, że kontrolę w tych obszarach sprawują również inne urzędy administracji, działalność NKU ma jednak charakter specjalny (Pavlíček a kol. 2015, 1028). J. Filip zasadnie, moim zdaniem, krytykuje również, że konstytucja nie ustanawia kryteriów kontroli (Filip 2010, Uwaga 44...); czyni to dopiero ustawa o NKU, która w $§ 4$ ust 1. wylicza, iż są nimi: legalność, stosowność (odpowiedniość), celowość, oszczędności, wydajność i kompletność (zupełność).

Zakres podmiotowy kontroli sprawowanej przez NKU, zgodnie z $\S 3$ ust. 2 lit. a i b, jest szeroki i obejmuje struktury organizacyjne państwa oraz osoby prawne i fizyczne. Najszerszy jest w przypadku tych pierwszych, trudno jednak uznać, aby było to określenie precyzyjne. Kontrolując gospodarowanie przez nie majątkiem państwowym bada, czy czynią to celowo, efektywnie i wydajnie (gospodarnie). W przypadku innych podmiotów kontroluje natomiast kwestie związane z otrzymywaniem zamówień publicznych i innych specyficznych działań. Badane jest też wykorzystanie funduszy strukturalnych Unii Europejskiej. Specyficzna, z uwagi na ich pozycję ustrojową, jest wreszcie kontrola Czeskiego Banku Narodowego i jednostek samorządu terytorialnego (Jirásek a kol. 2013, 317). Omawiając zakres podmiotowy kontroli NKU trzeba również wskazać na powszechnie przywoływany w czeskiej literaturze przedmiotu wyrok Sądu Konstytucyjnego, w którym uznał on, że w przypadku środków publicznych przyznanych z budżetu państwa partiom politycznym lub ruchom politycznych stają się one środkami podmiotu prywatnego i nie podlegają kontroli NKU, tym samym, w tym przypadku, nie można już mówić o gospodarowaniu majątkiem państwowym, o którym stanowi art. 97 ust. 1 Konstytucji ${ }^{22}$.

Przedstawiając Najwyższy Urząd Kontroli RCz trzeba też pamiętać, że nie dysponuje on uprawnieniami (środkami), które w przypadku stwierdzenia niedociągnięć, pozwalałyby mu na ingerencję, te należą bowiem do organu, któremu przekazuje on wyniki przeprowadzonej przez siebie kontroli (Filip 1994, 189).

${ }^{22}$ Wyrok Sądu Konstytucyjnego nr 296/1995. 
Kontrola przeprowadzana przez NKU odbywa się zawsze na podstawie planu, który na wniosek prezydenta NKU uchwala Kolegium NKU na okres roku budżetowego ( $\$ 17$ ustawy o NKU). Samo przeprowadzenie kontroli odbywa się według regulaminu kontroli, który również jest stosunkowo szczegółowo uregulowany w ustawie o NKU ( $§ 19-\S 31)$. Opierając się na nim, kontrolujący mają m.in. możliwość wejścia do obiektów i innych pomieszczeń kontrolowanych podmiotów, domagania się otrzymywania oryginałów dokumentów, zapoznawania się z niejawnymi dokumentami, otrzymywania niezbędnych informacji oraz korzystania ze środków telekomunikacyjnych kontrolowanych podmiotów.

Przeprowadzona analiza pokazuje ewolucję najwyższego organu kontroli począwszy od powstania Czechosłowacji po I wojnie światowej. Współcześnie Najwyższy Urząd Kontroli jest na mocy Konstytucji organem niezawisłym, którego zadaniem jest kontrola gospodarowaniem majątkiem państwowym oraz wykonania budżetu państwa. Lakoniczność tej regulacji nie pozwala na precyzyjne określenie jego pozycji ustrojowej i chociaż nie można uznać go za czwarty segment władzy, niewątpliwie jest ona specyficzna. Wątpliwości budzi również zakres przedmiotowy i podmiotowy sprawowanej przez niego kontroli.

\section{BIBLIOGRAFIA}

Bahýl'ová, Lenka, Jan Filip, Pavel Molek, Milan Podhrázký, Radovan Suchánek, Vojtěch Šimíček, Ladislav Vyhnánek. 2010. Ústava České Republiki. Komentář. Praha: Linde.

Bankowicz, Marek. 1998. Systemy władzy państwowej Czechostowacji i Czech. Kraków: Wydawnictwo PiT.

Filip, Jan. 1994. Ústavní právo. Díl 2. Brno: Masarykova univerzita.

Filip, Jan. 2001. Vybrané kapitoly ke studiu ústavního práva. 2. vydání. Brno: Masarykova univerzita v Brně.

Filip, Jan. 2010. Uwagi 2, 5, 6, 21, 33, 44, 46, 47, do art. 97. W Lenka Bahýlová, Jan Filip, Pavel Molek, Milan Podhrázký, Radovan Suchánek, Vojtěch Šimíček, Ladislav Vyhnánek, Ústava České Republiki. Komentár̆. Praha: Linde Praha.

Gerloch, Aleš, Jiří Hřebejk, Vladimír Zoubek. 1999. Ústavni system České Republiki. 3 aktualizované vydaní. Praha: Prospektrum.

Jirásek, Jiř́ a kol. 2013. Ústavní základy organizacje státu. Praha: Leges.

Klíma, Karel. 2002. Ústavni právo. Dobrá voda u Pelhřinova: Aleš Čěnek.

Klíma, Karel a kol. 2005. Komentář k Ústavě a Listině. Plzeň: Aleš Čěnek.

Mikule, Vladimir. 1993. „Nejvyšší kontrolní úřad po novu”. Správní právo 3.

Pavlíček, Vaclav a kol. 1998. Ústavní právo a státověda. I díl, Obecná státověda. Praha: Linde Praha.

Pavlíček, Vaclav a kol. 2015. Ústavni právo a státověda. Díl 2. Ústavni právo České republiky. 2. aktualizované vydání. Praha: Leges.

Pavlíček, Vaclav, Jiří Hřebejk. 1998. Ústava a ústavni raa České republiky. Komentár. Díl 1. Ústavní systém. 2 doplněné a podstatně rozšířené vydání. Praha: Linde. 
Pouperová, Olga. 2008. „Nezávislost nejvyšších orgánů účetní kontroly - organizační modely”. Contemporary Administrative Law Studies 3.

Sylwestrzak, Andrzej. 2006. Najwyższa Izba Kontroli. Studium prawno-porównawcze. Warszawa: Wydawnictwo Sejmowe

\author{
Akty prawne \\ Ustawa konstytucyjna nr 481/1991 Sb. \\ Ustawa konstytucyjna nr 1/1993 Sb. \\ Ustawa nr 175/1919 Sb. \\ Ustawa nr 99/1961 Sb. \\ Ustawa $\mathrm{nr} 7 / 69 \mathrm{Sb}$. \\ Ustawa nr 147/1970 Sb. \\ Ustawa nr 166/1993 Sb. ze zm. \\ Ustawa nr 90/1995 Sb. ze zm. \\ Ustawa $\mathrm{nr}$ 218/2000 Sb. ze zm. \\ Ustawa $\mathrm{nr}$ 219/2000 Sb. ze zm. \\ Ustawa nr 320/2001 Sb. ze zm. \\ Ustawa nr 137/2006 Sb. ze zm. \\ Rozporządzenie $\mathrm{nr}$ 73/1951 Sb.
}

\title{
Krzysztof Skotnicki
}

\section{THE SUPREME AUDIT OFFICE OF THE CZECH REPUBLIC}

\begin{abstract}
The article presents the genesis, evolution, current political position and the subjective and objective scope of the Supreme Audit Office of the Czech Republic. Its origins date back to the times of Czechoslovakia after the First World War. In later years, he was replaced by the Ministry of Control. The laxity of the current constitutional regulation of this body does not allow to precise determination of its political position, and although it cannot be considered as the fourth estate it is undoubtedly specific. The subjective and subjective scope of the control exercised by this body also raises doubts.
\end{abstract}

Keywords: state control function, state control, Supreme Audit Office, Czech Republic. 